\title{
Restriction Fragment Length Polymorphism Analysis
}

National Cancer Institute

\section{Source}

National Cancer Institute. Restriction Fragment Length Polymorphism Analysis. NCI Thesaurus. Code C17633.

Use of restriction fragment polymorphism for detection of point mutations or other chromosomal changes. 